\title{
ASSESSMENT OF A RECENT STATE COUNCIL DECISION ON ADDITIONAL CUSTOMS DUTY
}

\author{
Yetkin Kaan GENÇTÜRK ${ }^{1}$
}

\author{
Mevlüt UZUNÖNER ${ }^{2}$
}

\begin{abstract}
According to Article 73 of the Constitution, although taxes, fees, duties, and other such financial obligations can only be set by law, the executive authority shall be authorized to change the rates in such areas within the upper and lower limits specified by the law. On the other hand, pursuant to paragraph 2 of Article 167 of the Constitution, the executive may be empowered by laws to impose additional financial impositions for imported goods in order to regulate the foreign trade for the benefit of the country's economy.

In the study, additional Customs Duty imposed by the Decree No. 2015/7713 of Council of Ministers, claims during judicial process completed with the decision No. 2017/6611 of The 7th Chamber of the Council of State and the approval decision No. 2018/946 of Assembly of Tax Courts on request of appeal, the defense of Ministry of Economy and judgment of the Court, the principle of legality of tax and the scope of the exemptions regulated in the Constitution on the basis of legal regulations under the issue were examined.

In this context determinations made in the trial process and regulations on which those were grounded, especially "additional customs duty" conceptwhich is subject to proceedings, the scope and the legal nature of this concept, the decision of the court through some exemplary regulations of the executive has been criticized and evaluated as a result.
\end{abstract}

Keywords: Additional Customs Duty, Additional Financial Impositions, Decreeof The Council of Ministers, Tax Rate

JEL Code: K34, E62, H22.

\section{Introduction}

According to the Constitution, we can say that the taxation can only be made by the legislative authority, and that the executive body can be empowered to amend the rate of taxes within the upper and lower limits specified in the laws, yet the authority to impose additional financial impositions other than taxes and similar obligations to be collected from import, export and other foreign trade transactions can be transferred to the executive body by laws. ${ }^{34}$

It is observed that the executive body, which has the authority to impose financial obligations on imported goods with a constitutional basis, entitles additional financial impositions to be imposed by its current decisions in this context as "additional customs duty" and; in our study by choosing an exemplary decree of the Council of Ministers subjected to annulment suit and by assessing the relevant Decree by its characteristics within the limited scope of the current

\footnotetext{
1 Res. Asst., Istanbul University Faculty of Law Department of Fiscal Law, yetkinkaan@gmail.com

2 Res. Asst., Istanbul University Faculty of Law Department of Fiscal Law, mevlut.uzunoner@istanbul.edu.tr

3 The above definition has been made according to the 3rd and 4th paragraphs of the 73rd article and 2nd paragraph of the 167th article of the Constitution of the Republic of Turkey which was adopted by Law no. 2709.

${ }^{4}$ During the period of the Judicial Decisions on the Decree of the Council of Ministers to be examined, the executive body was referred to as the Council of Ministers. In order to avoid confusion we considered it appropriate to use the term "Executive Body" instead of using President or Councl of Ministers except for the articles directly taken.
} 
jurisprudence and examining it with the attitude of the executive, it is aimed to offer an insight to future regulations and judicial decisions.

In this context, first the relevant Council of Ministers' decree shall be explained, then the relevant legal legislation shall be mentioned, and finally, the legal characterization of the present Decree shall be made by summarizing the judicial process.

\section{The Facts}

\subsection{Decree of the Council of Ministers No. $2015 / 7713$}

Pursuant to the annex of the Decision dated 20/12/1995 No. 95/7606 Decree of the Council of Ministers No. 2015/7713, published in the Official Gazette numbered 29379 of 7 June 2015 and entered into force on the same date and as annexed to it "Additional Decision to the Decision of Import Regime", it has been decided to collect "additionalcustoms duty" at 30\% from certain goodswhich hold an ATR Movement Certificate and which originate outside Turkey or the European Union, and at $10 \%$ from components and parts of the goods. ${ }^{5}$ The regulations of the above-mentioned decree, which are important in terms of the communiqué are listed below. According to this, it has been concluded that;

- total tax rate calculated by the inclusion of additional customs duty imposed in accordance with the 2nd paragraph of the 2nd article of the Decree to current taxes cannot exceed the rates increased by $50 \%$ set out in the Law on Customs Entry Tariff Schedule No. 474, and in case of an exceeding, 50\% increment in rates set out in Law No. 474 shall apply,

- by the customs office, within the 3rd paragraph of the same article additional customs duty shall be collected separately from import taxes and other financial obligations to be recorded as income to general budget,

- $\quad$ within the 4th paragraph of the same article, rules and procedures which the customs duty is subject to shall be applied to additional customs duty to be collected,

- within the 1st paragraph of the 3rd article of the Decree, customs duty shall be collected at the rate set out in the section of "Other Countries" for relevant goodswhich hold an ATR Movement Certificate and which originate outside Turkey or the European Union, yet under Free Trade Agreements which Turkey is a party to, additional customs duty shall not be collected from the goods which are included in a cross cumulation system of origin in case of its certification of preferential origin,

- Finally, in accordance with Provisional Article 1 of the Decree, the provisions of this Decree shall not be applied in case bill of entry concerning the importation of the goods loaded before the publication date of this decree is registered one month after the publication date of this decree at the latest. ${ }^{6}$

\footnotetext{
5 For detailed information on the related goods and additional parts of the goods subject to additional customs duties see: http://www.resmigazete.gov.tr/eskiler/2015/06/20150607-4-1.pdf.

${ }^{6}$ For a detailed study on this issue (certainity/predictability of tax), see Cenker Göker, "Dış Ticaret İşlemlerine Konulan Ek Mali Yükümlülüklerde Öngörülebilirlik Illkesi Üzerine Bir Deneme”, Ankara Barosu Dergisi, 2013-1, s. 115-124.
} 


\section{Legal Basis of the Council of Ministers' Authority}

\subsection{Constitutional Bases and Relevant Legal Regulations}

\subsubsection{Legal Regulations concerning the 4th Paragraph of Article 73 of the Constitution}

According to the 3th paragraph of Article 73, "Taxes, fees, duties, and other such financial obligations shall be imposed, amended, or revoked by law." According to the 4th paragraph of the same article, "The President of the Republic may be empowered to amend the provisions concerning the percentages of exemption, exceptions and reductions in taxes, fees, duties and other such financial obligations, within the minimum and maximum limits prescribed by law." When the two paragraphs are assessed together, it could be said that even if fees, duties and other financial obligations in addition to taxes can only be regulated by legislative body, in case the executive body is authorized (Güneş, 2014: 198) it shall have the authority to amend the percentages of exemption, exceptions and reductions of the same financial obligations, within the minimum and maximum limits prescribed by law.

In this context for example, the authority to grant exemption from customs duties to be collected from certain ${ }^{7}$ tax-payers and other taxes, fees and duties is given to the executive under the 2nd article of Law No. 3283.

Another example is; in compliance with the 2nd article of the Law on Customs Entry Tariff Schedule No. 474 without prejudice to the provisions of international agreements which Turkey is a party to, the executive is empowered to increase customs duty rates and percentages of the goods listed in Customs Entry Tariff Schedule up to 50\%, to reduce them down to zero or to increase rates and percentages in the Schedule up to $50 \%$

\subsubsection{2nd Paragraph of the 167th Article of the Constitution}

An exception to the principle of legality of the tax regulated in the Constitution was introduced in paragraph 2 of Article 167 titled as "Supervision of markets and regulation of foreign trade". According to the article, the executive can be empowered to impose and abolish additional financialimpositions ${ }^{8}$ except taxes and other similar obligations on import, export and other foreign trade transactions. However, this authority may be granted only by law and for the purpose of regulating the foreign trade on behalf of the country's economy (Öztürk, 2016: 6566). It is necessary to underline that the authority granted here is more comprehensive than the authority granted under 4th paragraph of Article 73 (Oktar, 2018: 34). Moreover, additional financial impositions are excluded from taxes and similar financial obligationspursuant to the provision (Kaneti, 1989: 7-8).

\footnotetext{
7 Taxpayers mentioned in Article 1 of Law No. 3283.

8 On additional financial impositions not being different from tax and similar financial obligations see: S. Ateş Oktar, "Vergi Benzeri Mali Yükümlülükler Ek Mali Yükümlülükler ve Bir Totolojik Düzenlemenin Analizi", i.Ü iktisat Fakültesi Maliye Araştırmaları Konferansları, 37.Seri, 1996/1997.
} 
In this context, Law on Regulation of Foreign Trade No. $2967^{9}$ can be given as an example. Because the law sets out in the first three articles respectively the rules and procedures of exercise of the authority given to the executive by the Constitution to impose and abolish additional financial impositions except taxes and other similar obligations on import, export and other foreign trade transactions for the purpose of regulating the foreign trade on behalf of the country's economy and the authority to specify principles concerning these obligations.

\subsection{Relevant International Legislation}

The ratification act on the approval of the Agreement establishing World Trade Organization was published in the Official Gazette No. 22186 of 29 January 1995. In accordance with this Agreement and the Protection Measures Agreement attached to it, in order for a Member State to impose an additional tax under the motive of protection measure in imports, the Member State is required to propound that increased imports have produced serious damage to domestic manufacturers, thus to carry out an investigation according to the procedure provided for in the Protection Measures Agreement and to reveal this threat of serious damage as a result of this investigation. ${ }^{10}$

\section{The Attitude and the Judgment of the Court}

In this section the judicial process will be explained in essence through claims, defenses and Court's assessment as the main points of dispute. Within this framework in its lawsuit petition the demandant claimed that;

- the additional customs duty was contrary to the principle of legality of the tax regulated under Article 73 of the Constitution,

- the Council of Ministers did not have the authority to impose additional financial impositions,

- no customs or equivalent tax could be imposed on the goods which hold an ATR Movement Certificate,

- additional customs duty on high-tech products was contrary to public interest and international commitments of our country.

The Ministry of Economy, in his defense claimed that;

- the matter in dispute was established in order to protect the domestic branch of production within the authority given pursuant to Article 73 of the Constitution and Article 2 of Law No. 474,

- additional customs duty was not a new version of customs duty or additional financial obligation or a means of defense of trade policy,

\footnotetext{
9 In the Constitutional Court, an action of nullity was filed against the law, but the case was rejected by majority. For decision, see: http://www.kararlaryeni.anayasa.gov.tr/Karar/Content/85416187-8c0d-4398-a4e5-cf4794d5a 54d?excludeGerekce=False \&wordsOnly=False

${ }^{10}$ See: Law No. 4067 entered into force upon publication in the Official Gazette dated 29.01.1995 and approuved by this Law The World Trade Organization Establishment Agreement signed on April 15, 1994 and the articles 1, 2, 3, 4, 5, 7, 9 and 12 respectively of its annexement Protection Measures Agreement signed on April 15, 1994.
} 
- additional customs duty was not subject to the rules and procedures of investigation laid down in the annexment of WTO Establishment Agreement, Protection Measures Agreement, as it was subject to the rules and procedures which customs duty was subject to and thus was a customs duty in nature.

The 7th Chamber of the Council of State concluded in its decision No. 2017/6611 that;

- additional customs duty was not contrary to the principle of legality of tax since it was not a new tax and it was an amendment to current customs duty rates based on the authority given to the executive pursuant to Article 2 of Law No. 474,

- additional customs duty was not contrary to the principle of certainty of taxation due to the fact that the possible amendment by the executive was specified clearly in the relevant law,

- as applicable additional customs duty rates was set out taking account of countries where dual or cross cumulation system ${ }^{11}$ were applied under free trade agreements, since additional customs duty defined only as an amendment to current customs duty rates could not be considered as protection measure which is one of the additional financial impositions or means of defense of trade policy, the relevant decision was not contrary to national or international legislation as it was not subject to the rules and procedures of investigation laid down in the annexment of WTO Establishment Agreement, Protection Measures Agreement.

In the petition where the decision of the 7 th Chamber of the Council of State was appealed; it was claimed that;

- the necessary steps were not taken based on the recognition that the Ministry had resorted to protection measures for the purpose of protecting domestic production due to serious import increase concerning the goods in dispute,

- by referring the regulation as a new tax burden, it was contrary to the principle of legality of the tax.

Assembly of Tax Courts approved the decision of the Chamber with the same legal reasons and justification. In the justification of its opposing vote it was concluded that;

- the resolution of the dispute was bound to the specification of additional customs duty's nature which was imposed,

- in the letter of the regulation the term "additional" was used,12

- new rates were determined as additional rather than increasing the current rates,

- a new tax was imposed rather than an amendment to the tax rates due to the fact that additional customs duty was collected separately from customs duties and other financial obligations to be recorded as income to the general budget.

\footnotetext{
${ }^{11}$ For the definitions see: https://ab.gtb.gov.tr/ab-ile-iliskiler/mense-kurallari/mense-kurallari-ve-uygulamalarinailiskin-soru-ve-cevaplar

${ }^{12}$ For the opinion that even the use of the word "additional" may cause violaion of the principle of "certainty of taxation" see: Mualla Öncel/Ahmet Kumrulu/Nami Çağan, Vergi Hukuku, 26.Baskı.,Ankara, Turhan, 2017, s. 48.
} 


\section{Conclusion}

In conclusion, as it is seen in the relevant decisions of the executive, we can say that the executive deems the term additional customs duty under the authority to increase tariff rates given by the Law No. 474.

Another argument which can be included in this context is the 2nd paragraph of Article 167. According to the article, by law the executive can be empowered to impose and abolish additional financial impositions except taxes and other similar obligations on import, export and other foreign trade transactions for the purpose of regulating the foreign trade on behalf of the country's economy. In other words, the executive can impose additional financial impositions except taxes and other similar obligations on import only with an authority explicitly given by the relevant law. It is evident that this authority is not given by Law No. 474, but by Article 3 of Law No. 2976 entitled "Additional financial impositions."

Therefore, even though the decision No. 2015/7713 was considered as relevant to Article 73 of the Constitution both by the Ministry of Economy ${ }^{13}$ and 7th Chamber of the Council of State and Assembly of Tax Courts, as stated by the Council of State Prosecutor in the Decree no. $2017 / 6611$ of the 7 th Chamber of the Council of State, imports of small household appliances increased by $24 \%$ from 2012 to 2014. Although the additional customs duty imposed due to the increase in imports by the decision subject to the lawsuit can be considered as a customs duty in the sense that it is collected separately by other customs duties and it is imposed with a tariff schedule, since it contains a protection measure under WTO legislation the Court was required to decide on the issue taking account of Turkey's international commitments.

\section{References}

Anayasa Mahkemesi, 11.01.1995 Tarih ve E. 1984/6, K. 1985/1 Sayılı Karar, http://www. kararlaryeni.anayasa.gov.tr/Karar/Content/85416187-8c0d-4398-a4e5-cf4794d5a54d?e xcludeGerekce=False \&wordsOnly=False.

Göker, C. (2013). “Dış Ticaret İşlemlerine Konulan Ek Mali Yükümlülüklerde Öngörülebilirlik ilkesi Üzerine Bir Deneme”, Ankara Barosu Dergisi, 2013-1, s.115-124. http://dergipark.gov.tr/ download/article-file/398023.

Güneş, G. (2014). Verginin Yasalığı İlkesi, 4. Baskı, İstanbul, On İki Levha.

https://ab.gtb.gov.tr/ab-ile-iliskiler/mense-kurallari/mense-kurallari-ve uygulamalarina-iliskinsoru-ve-cevaplar.

http://www.resmigazete.gov.tr/.

Kaneti, S. (1989). Vergi Hukuku, 2. Baskı, İstanbul, Filiz Kitabevi.

Oktar, S. A. (1996/1997). "Vergi Benzeri Mali Yükümlülükler Ek Mali Yükümlülükler ve Bir Totolojik Düzenlemenin Analizi", i.Ü. İtisat Fakültesi Maliye Araştırmaları Konferansları, 37. Seri, http://dergipark.gov.tr/download/article-file/7373.

\footnotetext{
${ }^{13}$ With the Decree-Law No. 703, the Ministry of Customs and Trade and the Ministry of Economy are combined under the Ministry of Commerce.
} 
Oktar, S. A. (2018). Vergi Hukuku, 13. Baskı, İstanbul, Türkmen Kitabevi.

Öncel, M., Kumrulu, A. \& Çağan, N. (2017). Vergi Hukuku, 26. Bası, Ankara, Turhan.

Öztürk, i. (2016). Vergi Benzeri Mali Yükümlülükler, Ankara, Yetkin. 